\title{
Analysis and Countermeasures of Factors Affecting Farmers' Income Increase under the Background of Urbanization
}

\author{
Luo Xianghua ${ }^{1}$, Zhang Yingqin ${ }^{2}$ \\ International Business School, Shaanxi Normal University \\ Xi'an 710062, Shaanxi, China
}

\begin{abstract}
This paper studies the factors that affect the increase of farmers' income and analyzes the restricting factors of the income increase of rural migrants and left-behind farmers under the background of urbanization. It is proposed that advances should be made in the process of urbanization, such as raising the level of agricultural modernization, improving the overall quality of farmers, enhancing the circulation of land, and establishing a sound land transfer mechanism. Increasing farmers' income is the basis for the revitalization of the countryside. Realizing a prosperous life requires an increase in farmers' income. An analysis of the factors that restrict farmers' income increase plays a crucial role in increasing farmers' income.
\end{abstract}

Keywords-Farmers' income increase; Influencing factors; Urbanization; Revitalization of the countryside

\section{INTRODUCTION}

19th CPC National Congress put forward the strategy of revitalizing the countryside. The affluent life of the peasants is the basis for the revitalization of the countryside. Since the 19th CPC National Congress, China's rural poverty population has been reduced by 68.53 million. The incidence of poverty fell from $10.2 \%$ at the end of 2012 to $3.1 \%$, a cumulative decrease of 7.1 percentage points. However, at the end of 2017 there were still 30.46 million people living in the country's rural areas below the poverty line. To achieve the goal of revitalizing the country and affluent people, it is necessary to further lift the rural population out of poverty. The immediate need to get rid of poverty is to increase the income of farmers. Research on the constraints of increasing peasants' income has become crucial to poverty alleviation and farmers' affluence.

Domestic and foreign scholars have analyzed the factors affecting the increase of farmers' income. Yan Yanyan et al. (2014) proposed that the main factors constraining the increase of farmers' income are the urban-rural dual structure, the unreasonable agricultural structure, the decline in agricultural product prices, excessive surplus labor, narrow employment channels, and imperfect social security systems [1]. Zhu Jia (2017) proposed that factors that are not conducive to increasing farmers' income are mainly weak agricultural infrastructure, low level of agricultural industrialization, and lagging behind in rural labor training [2]. Jiang Changyun (2013) proposed that urbanization, aging, informationization and new industrialization, and changes in the mode of agricultural development will all have an important impact on the income growth of medium and longterm farmers [3]. Yasuyuki Todo (2011) advocates the use of new farming techniques and innovative planting varieties to increase farmers' income [4].Brian C. Briggeman (2007) finds that government subsidies can increase farm income. Under the influence of government subsidies, each group of farmers has an average income of approximately $\$ 40,000$. [5]IddoKan and Kimhi (2006) found that farmers' non-agricultural income is positively correlated with the education level of farmers [6].

Studies have systematically analyzed the factors that influence the increase of farmers' income. It is concluded that scholars believe that the process of urbanization will promote the increase of farmers' income. At the end of 2017, China's urban population was 81.47 million, an increase of 20.49 million over the end of the previous year; the proportion of urbanization reached $58.52 \%$, an increase of $1.17 \%$ over the end of the previous year, and the urbanization rate target in 2020 will reach around $60 \%$. Under the trend of urbanization, the rural population is divided into migrants who migrate to cities and towns, and peasants who stay in rural areas to carry out agricultural production and management. Therefore, when analyzing the constraints of peasants' income increase, they should also study the differences between the two groups.

\section{THE STATUS QUO DESCRIPTION}

\section{A. Per capita income gap between urban and rural residents}

There is a clear disparity in per capita disposable income between urban and rural areas in China. From Table 1, we can see that since 2010, disposable income of urban residents has been higher than the per capita disposable income of rural residents by more than 10,000 yuan. Since 2010, the Engel coefficient of urban residents is below $40 \%$, and it has been reduced to below $30 \%$ in the past two years. Compared with the Engel coefficient of urban and rural residents in recent years, the per capita income of rural residents is at a relatively low level.

\footnotetext{
'Author's introduction: Luo Xianghua (1994- ), Shaanxi Province, Master's degree in International Business School, Shaanxi Normal University, research direction: Social security.

${ }^{2}$ Zhang Yingqin (1963-), Female, Shaanxi Province, Professor of International Business School, Shaanxi Normal University, doctoral supervisor, doctor of law, research direction: social security.s).
} 
TABLE I. PER CAPITA DISPOSABLE INCOME AND ENGEL'S COEFFICIENT OF URBAN AND RURAL RESIDENTS IN CHINA

\begin{tabular}{ccccc}
\hline years & $\begin{array}{c}\text { Per capita } \\
\text { disposable income } \\
\text { of urban residents } \\
\text { (yuan) }\end{array}$ & $\begin{array}{c}\text { Per capita } \\
\text { disposable } \\
\text { income of rural } \\
\text { residents (yuan) }\end{array}$ & $\begin{array}{c}\text { Engel } \\
\text { coefficient of } \\
\text { urban } \\
\text { residents }\end{array}$ & $\begin{array}{c}\text { Rural residents } \\
\text { Engel's } \\
\text { coefficient }\end{array}$ \\
\hline 2010 & 19109 & 5919 & 35.7 & 41.1 \\
2011 & 21810 & 6977 & 36.3 & 40.4 \\
2012 & 24565 & 7617 & 36.3 & 39.3 \\
2013 & 26955 & 8896 & 35.0 & 37.7 \\
2014 & 29381 & 9892 & 35.6 & 37.9 \\
2015 & 31195 & 11422 & 34.8 & 37.1 \\
2016 & 33616 & 12363 & 29.3 & 32.3 \\
\hline
\end{tabular}

a. Source: China Statistical Yearbook 2017, Engel's coefficient for 2014, 2015, 2016 originated from China Industry Information Network.

\section{B. Comparison of Farmers' Income in Countries}

From Table 2, we can see that compared with other countries in the world, the income of Chinese farmers is at a low level. Since 2004, the income of peasants in Japan and the United States has been roughly 50-100 times that of Chinese peasants.

TABLE II. COMPARISON OF FARMERS' INCOME IN DIFFERENT COUNTRIES UNIT: USD

\begin{tabular}{cccccc}
\hline years & China & Japan & USA & Japan/China & USA/China \\
\hline 2004 & 513.81 & 26117.50 & 44904.46 & 50.83 & 87.39 \\
2005 & 541.10 & 27987.18 & 51062.30 & 51.72 & 94.37 \\
2006 & 569.08 & 29197.17 & 49378.20 & 51.31 & 86.77 \\
2007 & 590.43 & 33432.60 & 45001.87 & 56.62 & 76.22 \\
2008 & 623.25 & 38279.07 & 49847.09 & 61.42 & 79.98 \\
2009 & 650.92 & 37075.73 & 57767.37 & 56.96 & 88.75 \\
2010 & 681.04 & 39283.53 & 57194.10 & 57.68 & 83.98 \\
2011 & 713.13 & 42878.92 & 49816.70 & 60.13 & 69.86 \\
\hline
\end{tabular}

b. Note: The source of the data is the World Bank. The income of Chinese farmers is the per capita net income of rural residents. The income of farmers in other countries is called the per capita value added of

From the income gap, we can see that the income level of farmers in our country is relatively low and there is room for increasing income. Analyzing the factors that affect the income of farmers in our country is of crucial importance.

\section{CONSTRAINTS ON FARMERS' INCOME INCREASE}

\section{A. Constraints on Staying in Farmers' Income Increase}

The process of urbanization of the rural population is slow. In 2017, the number of urban population in China was 81.47 million, and the urban rate was $58.52 \%$, which was 8.57 percentage points higher than that in 2010, which was 1.17 percentage points higher than the rate of urbanization in China in 2016. In the same period, the urbanization rates of the United States, Japan, and the United Kingdom were 82\%, 94\%, and $83 \%$, respectively. Although the urbanization rate in China has been increasing, there is still a large gap with the developed countries. The long-term dualization of urban and rural areas has resulted in a large number of labor forces being stranded in rural areas, resulting in slower rate of agricultural productivity growth, fewer employment opportunities for peasants, farmers have been hindered from increasing income.
The level of agricultural modernization is low. Most agricultural products in China have low technological content, many labor inputs and weak competitiveness. Agricultural production methods are relatively backward, industrialized nursery and machinery plant protection levels are low, and modern agricultural science and technology and mechanization are lagging behind. Comparing with developed countries, we can see that there is a big gap between China's and foreign developed countries' agricultural modernization.

The comprehensive quality of agricultural human capital itself. The level of rural education and development lags far behind that of cities, which makes the scientific and cultural quality of agricultural population lower than the urban level and cannot meet the needs of agricultural modernization and development. Most peasants are conservative in their ideas and do not know how to use legal means to defend themselves, making the ideological and moral quality of farmers lower than the urban level. The quality of farmers will be affected by the economic level, educational conditions, and social customs 


\section{B. Restrictions on the Relocation of Farmers' Income} Increase

There are defects in the land transfer mechanism. Even if the relocated peasants waste land, they are reluctant to transfer the land. The second national land survey data shows that China's arable land area is 135.385 million $\mathrm{hm} 2$, and the country's per capita arable land is $0.101 \mathrm{hm} 2$, which is less than half of the world's per capita level. The country's arable land is reduced by 433 annually. Millions of acres [7], to a certain extent, wasted land resources and thus affected farmers' income. At the end of 2016, Shaanxi Province conducted a sample survey of 285 peasant households in the province. The surveyed peasant households only transferred $39.0 \%$ of the total arable land; the peasants who accounted for half of the total peasant households visited did not understand the rural land transfer policy; only $57.6 \%$ of the surveyed peasant households were surveyed. There are written agreements between the two parties in the transfer of land; the annual income per household per mu obtained through land transfer is about 1273 yuan, and about 286 yuan per capita[8]. The farmers in the province have insufficient income through contracted land for family management. $20 \%$ of income, and less than $10 \%$ of income obtained through transfer of land. According to the case study of Shaanxi Province in 2016, it can be concluded that the area of land transfer in China is small and slow, the implementation of policies is not in place, and the reduction of arable land results in a decline in agricultural production capacity, which is unfavorable to farmers' income increase.

There is not enough training for the transfer of rural labor. First, farmers lack understanding of employment skills training. Most peasants lack employment planning when they transfer to cities and towns. They do not recognize the importance of vocational training. Second, the quality of job training is low. The phenomenon of theoretical teaching and practical disconnection exists in the transfer of labor training for farmers. Third, the degree of innovation in training methods and means is low. At present, the skills training process for the transfer of labor to farmers is not targeted, and the training content cannot meet the needs of economic and social development. Most rural laborers have low cultural qualities and lack training after they go to towns.

Household registration policy. The dualistic household registration system restricts the free movement of the population and hinders the migration of surplus rural labor to cities and towns. Labor productivity cannot be effectively improved. It is difficult for the surplus labor force to obtain the same social treatment as urban residents after transferring from rural areas to cities. The segmented household registration system makes migration farmers face different employment opportunities.

\section{POLICY SUGGESTIONS}

Promote new urbanization. The first is to reform the agricultural system and cultivate new agricultural production and management entities. The second is to promote the development of professional farmers and farms, improve agricultural security, risk resistance and market competitiveness. The third is to improve the profitability and anti-monopoly capabilities of the agricultural industry chain by combining leading enterprises and cooperatives, and create conditions for farmers to better participate in the division of interests in the agricultural industry chain.

Accelerate the promotion of agricultural modernization. To improve the supply of agricultural products; to maintain the sown area; to lay out the superior agricultural products; to standardize the production of animal husbandry, aquatic products and horticultural products; to promote the production of pollution-free, green food and organic products; and to promote the transformation of large-scale irrigation areas and small-scale water conservancy facilities in rural areas. Strengthen the construction of farmland water conservancy; develop land consolidation and rehabilitation, increase the cultivation area; promote rural network construction; govern the integrated rural environment; cultivate new farmers who understand technology, culture, and management.

Improve the overall quality of farmers. Increase education investment in rural areas, especially in backward areas of economic development, fully implement nine-year compulsory education in rural areas, improve the level and quality of rural education, build a scientific rural vocational and technical education system, improve the scientific and cultural quality of farmers, and promote long-distance education on the Internet. Solve the current status of agriculture, improve the scientific and technological quality of farmers; organize cultural activities and legal education activities to enable farmers to use the law in life, enhance democratic management and ability to handle affairs in accordance with the law, and improve farmers' ideological and moral qualities.

Improve rural labor training and protection policies. The government should support rural labor training schools and institutions; improve the training and employment information system; disseminate training information through the Internet through the information platform to the village; provide subsidies for participating in various types of training and obtain professional qualification certificates; Increase investment in labor transfer facilities.

Establish and improve rural land circulation system. Through publicity, farmers are made aware of the land transfer policy measures and their significance and effectiveness; ensure that the terms and conditions of the land transfer contract are complete and the procedures are complete; strengthen supervision to prevent operators from changing land use; setting up a land transfer management department, disputes in the process of circulation can be resolved. According to the peasants' wishes, it is up to the peasants to decide whether or not the peasants' land will be transferred or transferred. 
Promote the public service system reform associated with household registration. Children of migrating populations may enter urban schools, establish a reasonable cost-sharing mechanism for the compulsory education for the children of the transfer population, and include the rural population of urban migrant workers in the basic endowment insurance and industrial injury insurance coverage for urban employees; and strengthen protection of employment and labor rights of the displaced population; Provide housing security for the displaced population. The central government should increase its investment in relocating populations in the economically backward regions of the central and western regions to ensure the equalization of public services.

\section{CONCLUSION}

In recent years, China's support for agriculture has continued to increase, and the income gap between urban and rural residents has gradually narrowed. However, the increase in farmers' income is still constrained by many factors, such as the slow progress of agricultural modernization, the low comprehensive quality of farmers, the imperfect land transfer mechanism, and the dual segmentation of household registration. There is still a lot of room for farmers to increase their income. It is necessary to analyze different farmers' groups and different constraints and to fall back on affordable agricultural policies, so as to increase farmers' income.

\section{REFERENCES}

[1] Dian Yanyan, Lei Na, Yang Hong. Research on Farmers' Income in Hebei Province and Measures to Increase Their Income[J]. Agricultural Outlook, 2014(10):29-33.

[2] Zhu Jia. Investigation and Thinking on Increasing Farmers' Income[J].Rural Economy \& Technology,2017(02):69-71.

[3] Jiang Changyun The Current Situation of China's Peasants' Income Increase and Its Medium- and Long-term Influencing Factors [J].Economics and Management Research, 2013(04):5-13.

[4] Yasuyuki,T.,\&Ryo,T.Impact of farmer field schools on agricultural income and Skills: Evidence from an Aid-Funded Project in Rural Ethiopia[J].Agriculture Ecosystems and Environment, 2011(30):1-34.

[5] Bihn,N.\&James,A.A quantile regression Decomposition of UrbanruralInequality in Vietnam[J]. Journal of Development,2007(27):18-28.

[6] Chul-Woo,K.,Peter,O.\& Daniel,O.Off-farm labor supply responses topermanent and transitory farm income[J].Agricultural Economics \& Resource Management,2006(1):59-67.

[7] Gui Deng, Zhou Wei. Some thoughts on reducing the current situation of China's arable land year by year [J]. Agricultural Science and Technology, 2014(06): 396-397.

[8] The current situation and thinking of land transfer in Shaanxi rural areas. Shaanxi Provincial Bureau of Statistics.Http://www.shaanxitj.gov.cn/site/1/htm1/126/131/138/15236.ht $\mathrm{ml}$. 